\title{
Lev Vigotski entre duas revoluções: sobre a questão da autodeterminação política do cientista ${ }^{\star}$
}

\author{
Vladimir Samuilovich Sobkin, ${ }^{\text {, } \star \star ~ T a t i a n a ~ A n a t o l y e v n a ~ K l i m o v a ~}{ }^{I I}$ \\ ${ }^{I}$ Institute of Education Management of the Russian Academy of Education, Moscou, Rússia

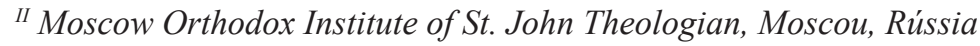

O presente artigo continua o ciclo de nossas publicações dedicadas ao período inicial da vida e das obras de Lev Semionovitch Vigotski (SOBKIN, 1981, 2015a, 2005b; SOBKIN; KLIMOVA, 2016; SOBKIN; LEONTIEV, 1994; SOBKIN; MAZANOVA, 2014a, 2014b, 2014c, 2014d, 2015). Ele se baseia em três notas publicadas na revista semanal Novi Put'(Novo Caminho), em julho e setembro de 1917. Essa revista era dedicada às questões da vida judaica e foi publicada em língua russa, em Moscou, entre janeiro de 1916 e outubro de 1917 (o redator da publicação era S. S. Kogan, também editor principal que ficou conhecido, posteriormente, como jurista soviético, criminologista especialista em direito criminal e também membro-correspondente da Academia de Ciências A. N. Trainin).

A revista Novi Put' era uma edição que pertencia à ala esquerda e isso se refletia no conteúdo dos materiais publicados que guardavam relação com os problemas internos da vida judaica e também com as questões gerais da cultura e da política. Na revista, publicavam-se trabalhos de famosos juristas, políticos, personalidades da ciência e da cultura $(\mathrm{O}$. I. Gruzenberg; A. N. Efros; C. G. Lozinski; G. A. Landau; Iu. I. Airrenvald; L. I. Katsnelson, entre outros).

A orientação geral da revista, publicada em língua russa, era determinada pela necessidade de interação entre as culturas judaica e russa. Como exemplo, podemos apresentar o artigo de A. N. Efros, "Tcherrov e os judeus", e suas publicações sobre a obra de M. Z. Chagal; o artigo de E. D. Kuskova "Os judeus e a inteligência russa" e a publicação de S. Ia. Schtraikh "As relações judaicas de I. I. Metchnikov", entre outros. A posição principal da revista a respeito da questão judaica se refletia nos trabalhos de um jurista conhecido como O. I. Gruzenberg (1866-1940). Ele apresentava-se como advogado que lidava com grandes questões judaicas (por exemplo, a acusação de judeus da cidade de Orsha de ataque à população camponesa em função de uma desavença religiosa; inquérito do pogrom de Kichiniov; inquérito de D. Blondes; inquérito de M. Beilis, e outros).

Chama a atenção o fato de que muitos autores da revista Novi Put' não apenas tinham formação em direito, mas, paralelamente, ocupavam-se da atividade do magistério (O. I. Gruzenberg; A. N. Trainin; Iu. I. Airrenvald). É possível que isso, precisamente, explique o convite a L. S. Vigotski para trabalhar na revista, como estudante da Faculdade de Direito da Universidade de Moscou e,

^Tradução do russo para o português de Zoia Prestes com a colaboração da Professora Elizabeth Tunes e da estudante do Curso de Pedagogia da Universidade Federal Fluminense (Niterói) Carolina Santos.

$\star \star$ Endereço para correspondência: Centre of Sociology of Education - a Institute of Education Management of the Russian Academy of Education. 125009, 9-4 Mokhovaya str., Moscow, Russia.E-mail: sobkin@mail.ru, t-klim@list.ru ao mesmo tempo, estudante da Faculdade de Filologia da Universidade Popular Chaniavski. Lev Semionovitch trabalhou nessa revista como secretário técnico, o que é comprovado por uma declaração em sua pasta pessoal que está guardada no arquivo central estatal da Rússia: TsGA RSFSR - F. 2306. - Op. 42. - D. 499. - L. 11 (VIGODSKAIA; LIFANOVA, 1996, p. 39).

Além das obrigações de secretário técnico na revista, Vigotski também publicava ativamente em suas páginas. Em um ano e meio de trabalho na revista, como conseguimos descobrir, ele publicou 11 materiais de diferentes estilos, incluindo artigos crítico-literários sobre Andrei Beli, M. Iu. Lermontov e artigos comemorativos dedicados à memória do escritor judeu e ativista social I. L. Gordon. Vigotski também publicou três artigos em que a questão central era a comparação entre acontecimentos históricos na vida sociocultural dos judeus e os processos contemporâneos que estavam acontecendo na Rússia. Esses artigos "Linhas enlutadas (Dia do 9 de Av)", "Pensamentos e ânimos (linhas para Hanucá)", "Avodimhoinu”.

Além dos trabalhos citados, entre março e setembro de 1917, nas páginas da revista Novi Put' aparece uma série de publicações de Vigotski que representam sua opinião direta sobre os acontecimentos políticos relacionados à revolução de fevereiro. Como não são publicações muito extensas, são escritas em estilo de reportagem e anotações informativas, eram publicadas nas seções que se intitulavam $\mathrm{O}$ judaísmo nos dias da revolução e $\mathrm{Na}$ província e não eram incluídas nas listas bibliográficas dos trabalhos dele. Praticamente, até hoje, eram desconhecidas. No entanto, a nosso ver, essas publicações são interessantes não apenas do ponto de vista informativo, mas porque também permitem (e isso se apresenta como o mais importante) caracterizar as peculiaridades das reações do próprio Vigotski à revolução de fevereiro e aos acontecimentos posteriores até outubro de 1917.

Neste artigo, apresentaremos três pequenas anotações de Vigotski publicadas na revista, completando-as com explicações que julgamos necessárias. Quando estávamos elaborando os comentários para esses textos, era importante para nós, em primeiro lugar, reconstruir brevemente o contexto social e político, ou seja, detalhes que foram "apagados da memória", ao longo desses cem anos que se passaram e que nem sempre são bem compreendidos pelo leitor contemporâneo. Isso articula-se ao papel de diferentes partidos políticos judaicos (Bun$\mathrm{d},{ }^{1}$ SERP, Poalei-Sion e outros) e, também, às atividades diversificadas das organizações sociais judaicas (EPO,

${ }^{1}$ Bund - União Geral Operária Judaica da Lituânica, Polônia e Rússia. Deste ponto em diante, a sigla utilizada será referente ao nome em português (UGOJLPR). A palavra bund, em íidiche, significa união. (N. da T.) 
OZE, ORT e outras). Além disso, precisamos chamar a atenção dos leitores para o fato de que Vigotski conhecia profundamente os detalhes da vida social e política da população judaica na Rússia.

Outra circunstância importante que estimulou nosso trabalho foi o desejo de destacar as avaliações essenciais de Vigotski que caracterizam as peculiaridades da população judaica na Rússia em relação aos acontecimentos revolucionários. É importante notar que, levando em consideração as determinadas formas de expressão, elas permitem reconstruir também a própria posição de Vigotski no período de transformações socioeconômicas radicais na situação política da Rússia e também a indefinição normativa moral. Com isso, podemos destacar que os processos de autoidentificação nacional e política se apresentam nele de forma orgânica e numa totalidade indivisível. Aqui, vale destacar que ele percebe, com sutileza, nos ânimos da população judaica, o presságio da futura tragédia.

Antes de apresentarmos o material, destacamos que, nessas pequenas anotações, com clareza, para ele se manifesta, em especial, a importante oposição entre a atividade partidária e a social: entre "o trabalho morto" e a vida viva da comunidade. No contexto de suas investigações pessoais e psicológicas, essa contraposição apresenta-se com extrema importância. Em primeiro lugar, encontramos nela a metáfora "trabalho morto" que reduz a atividade social "viva" ao funcionamento, à deformação dos sentidos fundamentais da atividade social. Em segundo lugar, a comunidade judaica manifestava-se para ele como uma unidade social fundamental que conserva, reproduz e, ao mesmo tempo, desenvolve tradições culturais e nacionais de um povo.

Finalmente, há mais uma linha que define o conteúdo dos nossos comentários. Ela está ligada ao desejo de mostrar as peculiaridades estilísticas de construção do texto, de desvendar suas peculiaridades em relação aos trabalhos de outros autores (por meio de citações ocultas), e, também, em relação aos trabalhos do jovem Vigotski e de seus textos posteriores.

Ao publicar essas pequenas anotações do autor, utilizamos as normas modernas da língua russa, com exceção de casos em que ele se vale de erros gramaticais propositalmente.

Depois desta pequena introdução, passaremos aos textos com nossos respectivos comentários.
Revista Novi Put', n. 24 e 25, de 15 de julho de 1917, colunas 30 e 31.

\section{Seção: Na província}

Gomel

\section{Eleições para a Duma municipal}

Finalmente acabaram as eleições para a Duma municipal. Seus resultados representam um significativo interesse social como valiosos indicadores da força e da influência de determinados partidos e grupos da população judaica de um centro provinciano relativamente grande.

Ao todo, foram apresentadas pelos partidos judaicos e grupos sociais cinco listas. Além disso, a UGOJLPR ${ }^{3}$ formou um bloco com organizações locais do Partido Socialdemocrata dos Trabalhadores da Rússia, ${ }^{4}$ com o Partido dos socialistas revolucionários ${ }^{5}$ e com a União

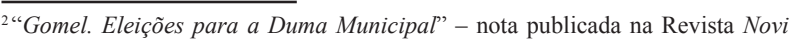
Put', de 15 de julho de 1917, na seção Na província, colunas 30 e 31 . O texto está assinado com as iniciais L. S. Essa nota de Vigotski, publicada em julho de 1917, reflete as peculiaridades dos ânimos políticos da população que vivia em "territórios demarcados para os judeus". Para sua compreensão, vale a pena levar em consideração que, logo após a revolução de fevereiro, iniciaram-se os preparativos das eleições para a Assembleia Constituinte. O governo provisório da Rússia, que assumiu o poder do país, após a abdicação de Nikolai II, deveria funcionar apenas até a convocação da Assembleia Constituinte. Em 14 de junho de 1917, foi anunciado que a data das eleições estava marcada para 17 de setembro de 1917, com a convocação da Assembleia Constituinte para 30 de setembro. No entanto, em seguida (9 de agosto de 1917), uma Resolução do governo presidido por A. F. Kerenski adiou a data das eleições para 12 de novembro de 1917. Com o anúncio da data das eleições para a Assembleia Constituinte (para 17 de setembro), em toda a Rússia teve início um trabalho político ativo para eleger representantes para os órgãos dos poderes locais (municipais, distritais, regionais, entre outros). Essa situação se reflete na nota de Vigotski sobre as eleições para a Duma Municipal de Gomel.

3 "Bund" - denominação da União Geral de Operários Judeus na Lituânia, Polônia e Rússia. O partido judaico socialista desenvolvia ações na Europa Ocidental desde os anos 90 do século XIX e era considerado o único representante dos interesses da numerosa população judaica da classe operária na Bielorrússia. Esse partido socialista de esquerda e marxista estava a favor da autonomia nacional e cultural, de um sistema laico de educação e do desenvolvimento da cultura em iídiche. A UGOJLPR (Bund) se contrapunha às tendências sionistas, sendo contra a imigração dos judeus para a Palestina. A sua ideologia estava instituída em quatro princípios: socialismo, secularismo, iídiche e doikait (pertencimento ao local de residência - "lá, onde vivemos, lá, é o nosso país" (estrofe de um poema de Ossip Mandelchtam - N. da. T.). Em 1890, a UGOJLPR (Bund) participou do I Congresso do Partido Socialdemocrata dos Trabalhadores da Rússia (PSDTR) e ingressou no partido como uma organização autônoma para questões do proletariado judeu. Em todas as etapas de sua atividade, participou ativamente da vida social das organizações e comunidades judaicas (educativas, culturais, filantrópicas, etc.). Após a revolução de fevereiro, o número de militantes cresceu até 30 mil pessoas. Com a pressão de representantes da organização nos sovietes de deputados operários e soldados em diferentes níveis, o Governo Provisório, em 20 de março de 1917, aboliu todas as 140 leis e resoluções que limitavam os direitos dos judeus em todas as esferas de sua vida social. Em março de 1921, a UGOJLPR (Bund) no território da Rússia, se autoliquidou e uma parte dela foi admitida no Partido Comunista Russo dos bolcheviques (PCR (b)).

4 "Organizações locais do Partido Socialdemocrata dos Operários da Rússia" - o Partido Socialdemocrata dos Operários da Rússia foi fundado em março de 1898 com a participação da "União Geral Judaica dos Operários na Rússia e Polônia". No II congresso em Londres, em 1903, ocorreu a cisão entre os mencheviques e os bolcheviques. Nas eleições para os órgãos centrais, os seguidores de Iu. O. Martov representavam a minoria e os de Lenin, a maioria. Os bolcheviques se orientavam pela hegemonia do proletariado na revolução que se aproximava e buscavam criar um partido de revolucionários profissionais. Os mencheviques tinham medo de criminalizar o partido. Os seguidores de Martov defendiam uma associação mais livre e sua orientação era burguesa liberal. Diferentemente dos bolcheviques, a palavra "menchevique" sempre foi informal, pois o partido sempre se denominou de socialdemocrata. Os mencheviques não defendiam o estabelecimento da ditadura do proletariado após a revolução que se aproximava e o nível ideológico e teórico deles, geralmente, estava acima do dos bolcheviques. Os mencheviques acreditavam que o proletariado deveria agir em coalisão com a burguesia liberal contra a monarquia na Rússia. Na primavera de 1917, os bolcheviques tomaram a decisão a favor da revolução do proletariado e se destacaram como uma fracção separada do Partido Socialdemocrata dos Operários da Rússia (dos bolcheviques) (PSDTR (b)).

5 "Partido dos socialistas revolucionários" - o Partido dos Socialistas Revolucionários surgiu com base na ideologia modernizada da narodnitchestvo (Zemlia e volia - "Terra e vontade", Narodnaia volia - "Vontade do Povo") e reconhecia o terrorismo individual. Este era o partido socialista não marxista mais numeroso e mais influente. Depois da revolução de fevereiro de 1917, o número de filiados 
Socialista Polonesa ${ }^{6}$ e, por isso, não apresentou uma lista separada, mas incluiu seus candidatos em uma lista geral do bloco socialista. É curioso, ao mesmo tempo, destacar que os demais partidos judaicos socialistas (Partido Unido - Serp ${ }^{7}$ e s.-t. - e Poalei-Sion) ${ }^{8}$ não se aliaram ao bloco comum socialista e formaram um bloco judeu socialista.

Foram lançados candidatos judeus separadamente e em listas gerais (proprietários de imóveis, bolcheviques, etc.).

No geral, o número de todos os judeus votantes (de um total de 101 pessoas) foi igual a 52 pessoas, o que corresponde aproximadamente à proporção numérica da população urbana.

A predominância significativa de socialistas (ao todo 65 pessoas) se refletiu também nas listas judaicas. Além de uma grande quantidade de votos dados pela UGO$J L P R$ (Bund) à lista geral socialista, o primeiro lugar foi ocupado pela lista do bloco socialista judeu, do qual foram eleitas 12 pessoas. Seguidos dos sionistas (7 pessoas), dos nacionalistas religiosos (4 pessoas) e de um grupo de ativistas sociais sem partido (2 pessoas).

atingiu 1 milhão e adquiriu uma posição hegemônica nos órgãos políticos locais de autogestão e na maioria das organizações sociais; ganhou as eleições para a Assembleia Constituinte. Os socialistas revolucionários (esser) se coligaram com o governo provisório (fevereiro de 1917), formando um bloco com os mencheviques resistentes. Eram membros do partido A. Kerenski, B. Savenkov, M Spiridonova e outros.

6"União Socialista Polonesa" - (PSO) desempenhou um papel muito importante no golpe de outubro na região ocidental. A União era liderada formalmente po Stefan Haltman, membro do partido socialista polonês do qual saiu posteriormente. O dirigente de fato dessa União era Stanislav Berson (nascido em Varsóvia em 1895 e fuzilado pelos correligionários poloneses em 21 de abril de 1919) que participou da luta pelo estabelecimento do poder Soviético na Bielorrússia. Foi um dos dirigentes da organização da socialdemocracia de Minsk do Reinado Polonês e Lituano (SDKP e L). Em 1917, passou a ser membro do partido comunista russo dos bolcheviques (PCR(b))

7 “...partido unido SERP (em russo, a palavra SERP significa "foice" - N. da T.)" - Partido Socialista Operário Judeu ("seimoistas" ou "seimistas") com orientação de esquerda. A primeira tentativa de criá-lo foi em dezembro de 1905; em 1906, ocorreu o primeiro congresso em que houve a eleição para o comitê central e a aprovação do programa do partido. Na revolução de 1905-1906, SERP liderou greves, participou de comitês da coalisão de diferentes partidos socialistas. Também se ocupava da organização de grupos de autodefesa dos judeus e também do movimento sindical. O partido desempenhou um papel importante no movimento estudantil e em atividades editoriais. O SERP tinha uma influência significativa nas regiões de Vitebsk e Maguiliovsk e tinha por base três princípios fundamentais: socialismo, luta revolucionária contra a monarquia e territorialização. Na questão nacional, defendia princípios do federalismo e a necessidade da autonomia nacional cultural. Com isso, dedicava uma atenção especial à vida dos judeus em comunidade, à organização de proteção à saúde ao apoio a camadas sociais frágeis da população judaica, à propagação de conhecimento, à organização de grupos de consumidores e produtores, à resolução de problemas da imigração judaica, à organização de estatísticas das questões da vida judaica. Considerava necessária a convocação da Assembleia Nacional Constituinte, a criação de grupos extraterritoriais do partido (seimos) que poderiam atender às necessidades nacionais e culturais de qualquer nação. A unidade nacional de autogestão se apresentava como uma comunidade judaica (kogal). Disso decorria uma das exigências mais importantes que era a democratização da vida em comunidade, a criação de sovietes regionais nas comunidades. Em maio de 1917, os membros do SERP se uniram com os socialistas-sionistas que, no texto da nota de Vigotski, estão indicados por "s.-t." (a total unificação e a criação de um único partido de operários judeus "OESRP" ocorreu em agosto de 1917). O OESRP apoiou o governo provisório.

8 "poalei-sion" - (Operários do Sião). Partido Judaico Socialdemocrata dos Operários. O primeiro grupo formou-se em 1901 na cidade de Iekaterinoslav. Seus representantes defendiam uma posição peculiar em relação à autonomia nacional na diáspora (halute). O programa do partido, elaborado em 1906, previa a socialização dos meios de produção e a reconstrução da sociedade para uma orientação socialista, baseada nos princípios e meios da luta de classe do proletariado judeu nas fileiras da socialdemocracia internacional. Apresentavam-se a favor da autonomia territorial judaica na Palestina e participavam ativamente da criação de grupos judeus de autodefesa. Após a revolução de fevereiro, até o verão de 1917, o número de filiados ao partido cresceu expressivamente (até 16 mil). O partido formou bloco com os mencheviques-internacionalistas e exigia ativamente a convocação da Assembleia Constituinte.
É muito significativo o último número. Um fracasso impressionante sofreu uma boa parte de organizações sociais populares locais (eleitores para a Duma da cidade, membros de todo tipo de comitês judaicos, etc.), apesar de, em parte, isso ser explicado pela insuficiente atividade do grupo durante a campanha eleitoral, porém, com muita nitidez, revela também a transferência radical de simpatias sociais e ânimos.

A campanha eleitoral, contra qualquer expectativa, não foi muito animada. Os mais ativos foram os socialistas e os sionistas. Os demais sequer se ouvia.

Em geral, as eleições refletiram com bastante precisão a realidade da vida social da cidade. Ela ficou toda concentrada no interior dos partidos que parecem se desencontrar em seu trabalho. Os grandes problemas judaicos e os que estavam na ordem das questões judaicas práticas comuns (conferência, congresso, estruturação da comunidade) ficaram à margem de toda essa atividade. O morador comum local teve, inevitavelmente, a impressão de que isso existe em algum lugar muito distante. Deus sabe quando ainda será (será que existe mesmo? será que existirá um dia?) e, de qualquer modo, não tem qualquer relação com isso. Exatamente por isso não pode ser compreendido como uma indiferença social. Ao contrário: assim que essas questões surgirem, em torno delas ocorrerá uma terrivel colisão ${ }^{9}$ de gostos, simpatias, visões, interesses, tendências que dilaceram a sociedade em partes inconciliáveis. Mas, por enquanto, passamos à margem de tudo isso, ao largo de algo grandioso e difícil.

\section{Revista Novi Put', n. 29, de 03 de setembro de 1917,} colunas 29 - 31.

\section{Seção: Na província}

\section{Notas da província ${ }^{10}$}

A frase clássica "o povo permanece em silêncio" 11 parece definir com maior precisão o verdadeiro estado das coisas na província. Não que o povo esteja calado: palavras, palavra, e palavras; falas, reclamações, declarações...

\footnotetext{
9 “...assim que essas questões surgirem, em torno delas ocorrerá uma terrível colisão". É preciso destacar que a nota de Vigotski foi publicada praticame ${ }^{0}$ nte às vésperas do fuzilamento na manifestação pacífica de julho em Petrogrado (35/16-18 de julho de 1917), que foi, inicialmente, convocada em protesto contra a continuação da guerra até a "vitória final", e depois se transformou em um protesto armado contra o governo provisório. Em relação a essa frase com a qual Vigotski termina sua nota, podemos dizer que é um testemunho de sua capacidade de sentir e diferenciar com sutileza os ânimos sociais e políticos no país.

${ }^{10}$ Notas da província - esse texto foi publicado na revista semanal Novi Put' ${ }^{0}$ 29 de 3 de setembro de 1917 na seção Na província, colunas 29-31. A nota está assinada com as iniciais L. S.

11 "O povo permanece em silêncio" - referência às últimas palavras da última cena da tragédia Boris Gadunov (1825) de A. S. Puchkin. O boiardo Massalski, um dos assassinos da viúva de Boris Godunov e de seu filho anuncia:

- Povo! Maria Godunova e seu filho Fiodor se envenenaram. Vimos seus cadáveres mortos ( $\mathrm{O}$ povo em terror fica em silêncio).

- Porque estão calados? Gritem: viva o príncipe Dmitri Ivanovitch! (O povo permanece em silêncio).

Essa referência final é um exemplo claro da generalização semântica, um exemplo de "tomada de sentido pela palavra". Aqui, diferentes linhas do enredo da tragédia, tendo em vista as relações, a luta pelo poder, a fidelidade e a traição, são transferidas para um nível totalmente diferente, quando a intriga política entre diferentes grupos passa para o nível de relações de "poder e povo". Vale notar que esse é exatamente o aspecto de conexão de diferentes linhas e níveis de desenvolvimento da ação e era extremamente importante para Vigotski na análise das obras de arte. Por exemplo, a contraposição do "drama familiar" de Hamlet (relação com a mãe, com o tio, com Ofélia), de um lado, é um conflito político (Hamlet - Fortinbras) e, de outro, Vigotski faz dele o momento central do seu trabalho sobre Hamlet.
} 
Acredito que, em nenhum lugar ainda, houve tal inundação de palavras. ${ }^{12}$ Porém, num determinado sentido, essas palavras permanecem profundamente justas quando empregadas para os judeus provincianos do antigo território demarcado ${ }^{13}$ e são justificadas pela realidade viva.

À primeira vista pode parecer que a população judaica reagiu com vivacidade a tudo que ocorreu na Rússia e participa ativamente da construção do novo governo, "amplia, aprofunda e reforça as conquistas da revolução"14 localmente; que a revolução provocou novas forças para a vida entre os judeus, fez com que os judeus provincianos A própria frase "o povo permanece em silêncio" é normalmente analisada como
distanciamento do povo em relação ao poder. Além disso, as interpretações po-
dem ser diferentes, o que testemunha também as inúmeras decisões da direção
de encenação dessa tragédia. Por exemplo, isso pode ser interpretado, dizendo
de outro modo, como a obediência cega do povo ao poder, ausência de vontade e
de coragem para defender seus interesses. É possível também outro entendimen-
to: quando o sentimento popular está orientado para outro sistema de valores
morais, o silêncio é uma posição moral de não aceitação do falso poder. Assim,
logo no início da nota, Vigotski, com sua referência a Puchkin, orienta o leitor
para um "diapasão moral especíico" que, necessariamente, precisa ser mantido
para compreensão de seu texto.
Para o leitor contemporâneo basta prestar atenção também à própria data da
publicação da nota - início de setembro de 1917. Vale lembrar que, depois da
abdicação de Nikolai II e a transferência do poder para o Governo Provisório,
foi proposta uma nova Assembleia Constituinte com a qual deveria se formar
o poder legítimo no país. As primeiras eleições para a Assembleia Constituinte
foram marcadas para setembro (17 de setembro de 1917$)$. No entanto, a situa-
ção política em Petrogrado era extremamente tensa: praticamente logo após a
abdicação de Nikolai II (2 de março de 1917$)$, instituiu-se uma dualidade de go-
vernos - Governo Provisório e Soviet de Petrogrado, o que vigorou até o início
de julho. Após o fracasso do ataque no front (3-4 de julho de 1917), os bolche-
viques organizaram uma manifestação política e empreenderam a tentativa de
derrubada do Governo Provisório. A manifestação foi fuzilada e teve início uma
repressão aos bolcheviques e, assim, o Governo Provisório conseguiu submeter
a si os Sovietes. Em setembro, a situação social e política ficou mais tensa: der-
rotas nos fronts, a cisão do Partido Socialdemocrata dos Operários da Rússia,
a tendência por parte de uma fração de bolcheviques à revolução proletária por
meio de um levante armado, etc.

12 "palavras, palavras, palavras... nunca houve essa inundação de palavras" - ao comentar essa passagem, vale a pena chamar a atenção para três momentos. Primeiramente, é evidente a referência à tragédia Hamlet. A resposta de Hamlet à pergunta de Polônio ("O que está lendo, príncipe?/ ... palavras, palavras, palavras..."). Essa frase tornou-se uma locução que significa o vazio e a falta de essência. Em segundo lugar, vale notar que a frase "palavras, palavras, palavras" é uma citação imprecisa de Shakespeare. Do nosso ponto de vista, é possível também uma referência velada de Vigotski ao conto de A. P. Tcherrov que se intitula da mesma forma Palavras, palavras, palavras. Vale também lembrar que é um conto sobre uma prostituta e um telegrafista. Não é casual que Tcherrov parafraseie Hamlet, pois os dois personagens de seu conto, brincando de honestidade, mentem um para o outro num espetáculo ruim: não demonstram um comportamento vivo, mas chavões usuais, chavões literários. Por isso, o conto termina com as palavras: "Que música vulgar!" Se levarmos em consideração o contexto em destaque, então, a utilização por Vigotski dessa expressão idiomática ("palavras, palavras, palavras") tem ainda uma característica valorativa nitidamente expressa da de falsidade e vulgaridade da retórica política que é própria desse período. Em terceiro lugar, antecipando-se, essa frase pode ser relacionada com a frase final da nota: "como diz o Talmude, não vemos as coisas como elas são e sim como nos parecem". Vale a pena nos voltarmos para o Talmude, pois a frase ("palavras, palavras, palavras") comentada pelo Talmude Babilônico, pode ser relacionada ao problema do papel da fala. "Não serás um divulgador de maledicências a respeito dos teus e não sujeitarás a julgamento o sangue do teu próximo" (Talmude, Vaicrá (Levítico) 19:16). Como "golpes de palavras", as expressões podem ter uma força destrutiva e acarretar um prejuízo irreparável. Assim, aqui pode-se notar mais um aspecto semântico: a agressividade é a ofensa que pode causar a "inundação de palavras". Vale destacar que não é fluxo, mas "inundação" de palavras, que, indiretamente, orienta o leitor para o contexto bíblico.

13 "Antigo território demarcado" - território em que era permitido aos judeus fixar residência permanente. Aqui, é importante destacar a utilização por Vigotski da palavra "antigo". Em 2 de março de 1917, o Governo Provisório, em sua primeira Declaração, anunciou a necessidade de revogar todas as classes sociais, as limitações em relação à crença e às nacionalidades. Na noite de 21 de março de 1917, o decreto foi assinado; entrou em vigor no mesmo dia; os judeus tornaram-se cidadãos plenos da Rússia. É exatamente esse aspecto que Vigotski destaca na nova situação socioeconômica e sociocultural, nomeando o território demarcado como antigo. Do nosso ponto de vista, é importante chamar a atenção para a atualidade da vivência de Vigotski da nova identidade civil expressa na frase.

14 "Amplia, aprofunda e reforça as conquistas da revolução" - palavras-chave da retórica revolucionária, clichês verbais muito encontrados no discurso sociopolítico do período revolucionário. apáticos e sempre à margem comungassem do grande fenômeno político. ${ }^{15}$ Na realidade, as manifestações, as reuniões para organização, os colegiados, as conferências distritais, regionais e locais são fenômenos que estão presentes em todos os lugares. Não apenas nas capitais, como antes, mas "trovejam os oradores, ferve a guerra verbal". ${ }^{16}$ Muito pouco restou do "silêncio secular".

Entretanto, basta olhar com mais atenção para tudo isso e perceber que é apenas uma ilusão, uma atividade morta, é ficar no mesmo lugar. Toda a atividade política está nos limites do partidarismo, se esgota com "atividades de estudo" das organizações que se enfileiram e refazem suas filas, declaram algo, se reúnem em conselhos, se preparam. Tudo isso é um trabalho intrapartidário. Partido não se toca com partido, não se encontra sequer em seu trabalho, ninguém e nada retiram-no de seu círculo de atividades de organização interna instituida. Caso alguém consiga sair, é apenas quando assim exigem as circunstâncias politicas gerais: nos Sovietes dos Deputados dos operários, nas Dumas Municipais. Na esfera da vida social judaica não existe questão ou trabalho que promova sua colisão.

\footnotetext{
15 “...fez com que os judeus provincianos apáticos e sempre à margem comungassem do grande fenômeno político" - essa frase, a nosso ver, tem um interesse semântico peculiar. O judaísmo (assim como o islã) não conhece o segredo da comunhão, que surge apenas com o cristianismo e consiste na sagração do pão e do vinho como Corpo e Sangue de Jesus Cristo. A comunhão (sagração do pão e do vinho) permite ao fiel unir-se a Deus e é necessário ao homem para salvação da alma. Nesse sentido, a expressão que se refere à comunhão dos judeus, no entendimento comum, é oxímoro (um procedimento estilístico, composição não combinável). Por isso, a "comunhão de judeus" pode ser analisada como união com algo que é estranho. Ao mesmo tempo, no contexto, tal frase pode ter também um outro sentido: comunhão com outra crença, com uma nova espiritualidade que deve servir à revolução. Vale acrescentar que a estilística desse fragmento, do nosso ponto de vista, caracteriza os valores do próprio Vigotski. Por um lado, é o sentimento de si na fronteira entre duas culturas (judaísmo e cristianismo): ele escreve sobre os judeus e, ao mesmo tempo, toca em contextos profundos, culturais e semânticos do cristianismo (comunhão). Por outro lado - "comunhão com a revolução" - permite revelar certos matizes semânticos da reação positiva dele aos acontecimentos da revolução de Fevereiro.
}

16 “....como antes 'trovejam guerreiros, ferve a guerra verbal'. Muito pouco restou do "silêncio secular" - as frases finais desse parágrafo foram tomadas por Vigotski dos versos de N. A. Nekrassov de 1860:

Nas capitais há barulho, trovejam oradores,

E ferve a guerra verbal.

E lá, nas profundezas da Rússia-

Há um silêncio secular.

O vento não dá sossego

Aos cumes dos chorões marginais,

E as espigas dos campos infinito

Curvam-se em aros

E beijam a terra-mãe..

Nesse verso, revelou-se o ceticismo de Nekrassov em relação às "grandes reformas" que se aproximavam e à "coragem" dos artigos que eram publicados na imprensa da capital. O verso foi censurado. Conhece-se a sua primeira versão (1857 - carta a I. S. Turguenev). A comparação de diferentes fragmentos do texto mostra que a denominação "silêncio secular" surge apenas numa versão mais tardia. Inicialmente, havia as seguintes estrofes: "e lá, nas profundezas da Rússia,/O que há lá?.. Deus sabe... Não dá para entender!../Há um silêncio". Depois, surgiu mais uma versão: "O que há lá? Um silêncio mudo...” E, finalmente, o "silêncio secular". Vale chamar a atenção que tais substituições fixam a "apalpação do sentido" peculiar que determina para Nekrassov uma característica fundamental da situação na Rússia. Essa situação, é claro, é sentida por Vigotski, mantendo a contraposição-chave de "silêncio secular" e "tempestades políticas" à espera das reformas. Gostaríamos de sublinhar que a relação irônica e desdenhosa de Nekrassov em relação à própria importância de mudanças políticas mostra-se relevante para Vigotski ao avaliar a situação do outono de 1917. Acrescente-se que a utilização da palavra antiga "oradores" [a palavra utilizada em russo é antiga - vitii - N. da T.] (pessoa eloquente, falante) refere-se a Puchkin e a seu famoso poema Aos caluniadores da Rússia ("Porque trovejam, oradores do povo?"). E vale lembrar que, nesse poema, Puchkin acentua em particular a atenção nas relações nacionais internas da Rússia: "debate de eslavos entre si" - é uma frase que se tornou metafórica. 
É claro que isso está ocorrendo pelo mesmo motivo: é um trabalho morto, ${ }^{17}$ que não tem relação com a realidade judaica atual. Tudo isso acontece nos limites desta, passa batido, sem atingir e até sem tocar o "giro" normal do círculo do partido.

Em praticamente nenhuma cidade do território demarcado, será possível ouvir que nas reuniões, nos relatórios, nas manifestações, nas conferências, tenha se falado do congresso judaico, ${ }^{18}$ a não ser de forma superficial e passageira. A opinião pública não está interessada nem um pouco nesse congresso. As questões a ela atinentes não são debatidas em lugar algum.

\footnotetext{
17 "Trabalho morto" (ver também acima "atividade morta") - a nosso ver, a característica do trabalho (atividade) humano como morto é extremamente importante do ponto de vista psicológico. Na verdade, a metáfora de Vigotski agudiza a contraposição entre o vivo e o morto. O último caracteriza o funcionamento social, livre de relações internas com os profundos fundamentos da vida da personalidade no espaço da cultura. Vale sublinhar que para a compreensão das futuras investigações propriamente psicológicas de Vigotski, a oposição "morto-vivo" revela-se conceitualmente importante. Essa posição peculiar da fenomenologia em relação aos fenômenos psicológicos como manifestações vivas é própria do autor. Por exemplo, vale lembrar a contraposição da palavra viva palavra morta que é apresentada como uma moldura peculiar no sétimo capítulo do livro Pensamento e fala. A epígrafe deste capítulo é a frase tomada de $\mathrm{O}$. Mandelchtam: "Esqueci a palavra que queria dizer/ e a ideia infértil retornará ao palacete das sombras", e o capítulo e o livro se encerram com a frase do poema de N. Gumiliov: "como abelhas numa colmeia abandonada/cheiram mal as palavras mortas". Entre os seguidores de Vigotski, V. P. Zintchenko atribuía uma ênfase especial à necessidade de levar em consideração a realidade psicológica viva, discutindo, por exemplo, o "movimento vivo" em seu trabalho monográfico A bengala de Mandelchtam e o cachimbo de Mamardachvili. Pode-s também, nesse caso, lembrar o exemplo apresentado por A. N. Leontiev em suas aulas com os detentos, que eram obrigados a realizar um "trabalho morto": carregar água de um buraco no gelo para outro. Com isso, Leontiev destacava importância do avivamento da atividade, da atribuição de sentido, o que, possivelmente, atualizava a personalidade dos detentos.
}

18 “...falavam do congresso judeu” - para a compreensão do tema sobre a necessidade de convocação de um congresso judeu é preciso levar em consideração que essa questão surgiu em função da aprovação pelo Governo provisório do decreto que havia sido preparado pelo Ministro da Justiça (naquela época, o cargo de ministro era ocupado por A. Kerenski) com a participação dos membros do bureau Político e de informação dos deputados judeus da Quarta Duma Governamental. Esse ato legislativo (publicado em 22 de março de 1917) revogava toda "as limitações nos direitos dos cidadãos russos que propagavam uma determinada crença, um pertencimento religioso ou uma nacionalidade". Na Rússia, tais limitações eram reguladas por aproximadamente 140 documentos normativos. Assim, estava sendo alterada a base normativa que regulava a vida política, social e econômica dos judeus e de outras nacionalidades que residiam na Rússia. E foi exatamente em função disso que surgiu a necessidade de convocação do Congresso Russo Judeu que deveria elaborar as exigências para apresentação ao governo, antes mesmo da convocação da Assembleia Constituinte, marcada, inicialmente, para setembro de 1917. Vale ressaltar que a necessidade de convocação do Congresso Judeu era uma demanda de representantes de diversos partidos judaicos. A título de ilustração, vamos apresentar um fragmento da Resolução Sobre a Realização da Autonomia Nacional e Cultural da X Conferência da UGOJLPR (Bund), que ocorreu em abril de 1917: "Com a aprovação de uma lei específica da Assembleia Constituinte devem ser criadas instituiçõe públicas normativas locais, regionais e estatais, com base no direito eleitora geral, igualitário, direto e secreto, sem distinção de gênero, para organizações e direção de toda a vida cultural da nação judaica na Rússia...”. Destaca-se que é exatamente para a importância da convocação do Congresso Russo Judeu que Vigotski chama a atenção, entendendo, como advogado, que a retirada das limitações exigia a preparação de uma nova base normativa legal para regular a vida dos judeus e, em primeiro lugar, a vida da comunidade judaica como a principal estrutura social. Deixando algumas questões de lado, pode-se supo que o próprio entendimento da importância das relações sociais (nesse caso, a sua regulação normativa-legal) apresenta-se como um dos princípios-chave, sobre os quais, posteriormente, será estruturada a psicologia histórico-cultural: fora do meio cultural é impossível também o desenvolvimento da identidade nacional. Vale notar que semelhante compreensão, formulada pelo jovem Vigotsk em um nível ideológico, expande essencialmente as ideias tradicionais sobre o desenvolvimento cultural como mediação sígnica. Como se vê pelo texto da nota do autor, é exatamente na organização da vida em comunidade que ele via unidade estrutural social que garante a formação da autodeterminação nacional e cultural. Retornando ao tema da necessidade de convocação do Congress Judeu, é importante ter em mente que existia outro ponto de vista. Por exemplo, um grande historiador que estudou as especificidades da vida dos judeus na Rússia, S. M. Dubnov, escreveu sobre a convocação do Congresso Judeu: "Seria possível construir o alicerce durante o incêndio?"
Outro exemplo seria a construção ou a reorganização da comunidade (obshina). E mais, nada se faz nessa direção. Há um fato, quase onipresente, que com muita nitidez demonstra os ânimos dos judeus da província. Esse fato é o total desvio da atenção da opinião pública de tudo que compõe a vida da comunidade judaica. Nas cidades com uma população judaica de dezenas de milhares, as organizações sociais, em torno das quais ainda há pouco fervia uma luta apaixonada, estão abandonadas por completo. OPE, OZE, ORT, ${ }^{19}$ sociedades de auxilio aos pobres, entre outras, não podem convocar uma reunião em função do pouco interesse em relação ao trabalho delas. A situação dos comitês de refugiados, em muitos lugares, é extremamente difícil.

Muitas instituições sociais vivenciam uma terrivel crise: não há militantes. No entanto, de tudo isso se compõe a vida comunitária. A comunidade vivencia, em geral, um declínio indubitável e profundo.

Porém, a imprensa provinciana nascente fala da atividade imediata, das questões grandiosas e de grande importância que surgiram diante dos judeus.

A província como sempre se acostumou a pensar que ela não deve se ocupar de política: os centros é que sabem. Apenas nas administrações municipais do partido "ganham posições", fazem uma enérgica campanha

"OPE, OZE, ORT, sociedade de auxílio aos pobres, etc...." - instituições judaicas sociais assistenciais beneficentes. Vale dizer que a atividade assistencial é a base da existência da comunidade judaica, que permite estabelecer a relação entre as pessoas e suas responsabilidades de ajudar ao próximo. OPE - sociedade de propagação do conhecimento entre os judeus na Rússia, uma das mais antigas organizações sociais judaicas. Seu estatuto foi aprovado pelo governo em outubro de 1863. A sociedade era mantida pela elite comercial e outros empresários. Participavam de suas atividades representantes da cultura judaica que lutavam contra o conservadorismo religioso das massas judaicas. A sociedade apoiava estudos científicos e atividades artísticas. Uma atenção especial era dada ao apoio de estudantes. Vale destacar que, em Gomel, nesse período, a OPE era dirigida pelo pai de Vigotski - Simcha ou Simão (Semion) Lvovitch Vigodski, o que é comprovado também, em particular, pelo texto de felicitações dirigidas ao poeta judeu R. N. Bialik, publicado na Revista Novi Put' (de 1916, No 13-14 de 24 de abril, pp. 44-46) e assinado: "Comitê do Departamento da OPE de Gomel, Presidente S. Vigodski". O texto das felicitações publicado está guardado no arquivo da família de Vigotski. OZE - a Sociedade de proteção à saúde dos judeus surgiu por iniciativa do grupo de ativistas sociais judeus, em agosto de 1912 em Petersburgo. O objetivo dessa sociedade era realizar estudos das condições sanitárias e higiênicas da vida dos judeus, propagação entre eles de informações atualizadas relacionadas à medicina e higiene. Um dos objetivos principais da sociedade era a criação entre os judeus de um serviço social único de proteção à saúde. A sociedade realizava um trabalho intenso de proteção à maternidade e aos recém-nascidos; de ampliação da rede de creches, jardins de infância, colônias de férias; organizava serviços ambulatoriais e dispensários, policlínicas itinerantes, apoiava o fornecimento gratuito de medicamentos aos necessitados, examinava o estado físico e psíquico das massas judaicas. Em agosto de 1917, funcionavam 45 filiais da OZE em 35 regiões. ORT - a Sociedade de trabalho artesanal e agrícola era uma organização que tinha como objetivo a propagação e o estímulo, entre os judeus, do trabalho profissional e agrícola qualificado. A principal ideia de criação dessa sociedade pertence ao famoso cientista e escritor, professor de fisiologia na Universidade de São Petersburgo, N. Bakst, que estava convencido de que apenas a formação e a instrução em profissões úteis poderiam garantir o futuro dos judeus russos; os judeus pobres e oprimidos do "território demarcado" simplesmente não sobreviverão se não aprenderem a se sustentar e às suas famílias com o próprio trabalho. Bakst pensou não apenas o plano de criação da organização, mas convenceu da importância de sua ideia o grande magnata ferroviário Samuil Poliakov (1836-1888). Graças aos esforços do barão G. Guintsburg foi possível conseguir a benevolência dos governantes e, em 22 de março de 1880, foi obtida a permissão para a formação do Comitê Provisório da ORT. Da sua composição faziam parte empresários judeus, o rabino de São Petersburgo e representantes da intelectualidade judaica da capital. Foi criado um fundo especial de apoio às atividades da ORT. O fundo colaborava com o restabelecimento econômico dos judeus russos (auxílio para a mudança de residência dos artesãos fora do "território demarcado", auxílios para compra de equipamento, ajuda às vilas agrárias, criação de mais de centenas de escolas profissionais). Durante a Primeira Guerra Mundial, o fundo auxiliou refugiados e migrantes na busca por emprego, na organização de cursos de instrução para adultos. Atualmente, a ORT é uma organização mundial influente de instrução e assistência. 
eleitoral e calculam forças. Resumindo, os resultados das eleições, quase em todos os lugares, mostram que a quantidade de cadeiras ocupadas pelos judeus, com bastante precisão, é proporcional à população judaica local. Apenas raramente isso é encoberto pelos blocos, pelos acordos, pelo absenteísmo, ${ }^{20}$ etc.

Uma parte significativa dos judeus da província, quiçá a mais significativa, exatamente a que permaneceu fora dos partidos não é apenas politicamente indiferente, não comunga com a revolução, permaneceu fora da política e, no interior da comunidade judaica, não se "autodeterminou”, não revelou sua relação com as diferentes tendências. Entretanto, a ela pertence a última palavra.

Em seu silêncio ${ }^{21}$ amadurece, acredita-se, uma grande cisão. Porém, por enquanto, a comunidade judaica da província está unanimemente sem ação e calada. O estado de confusão e profunda perplexidade não a abandona.

Essa perplexidade não se desfaz apenas com as questões: o que fazer e a quem seguir? Os motivos, indubitavelmente, são mais profundos e complexos. Eles estão na crise, no movimento geral que vivencia, principalmente, a comunidade judaica na província.

A prova mal sucedida pela via política e a reação negativa à revolução são apenas manifestações particulares da grise geral. Uma parte significativa dos judeus permaneceu apolítica e fora da revolução.

E se os partidos querem contar com ela, não devem educar politicamente as massas, mas criar de novo dessa parte significativa "massas políticas judaicas". Até agora não foi pronunciada uma palavra sequer que chamasse sua atenção para a politica.

A única coisa que ainda provoca reação viva nos judeus da província é o que restou do velho regime, aquilo com que todos já se acostumaram. As tentativas de pogroms, ${ }^{22}$ na verdade, não muito sérias, não são, contudo, casos isolados e insignificantes, mas refletem os ânimos da população contra os judeus e tudo isso atrai os olhares preocupados de todos. Os ânimos pessimistas a esse respeito não são tão raros assim. Todas as dificuldades governamentais (a questão de abastecimento de produ-

\footnotetext{
20 "Absenteísmo" - a recusa dos eleitores em participar nas eleições (do latim absens, absentis - ausência, do inglês - absenteeism); num sentido mais amplo é o comportamento político que se caracteriza pela falta de ação, recusa de qualquer participação política (de atividade eleitoral, partidária, participação em protestos e manifestações, etc.).

21 "Em seu silêncio..." - consideramos importante o surgimento dessa frase no escopo geral do texto de Vigotski porque com essa composição faz o leitor retornar ao início do artigo: "o povo permanece em silêncio". Vale notar que para o estilo dos trabalhos de Vigotski, esse momento de retorno peculiar, de "fechamento" do início e do fim do texto é muito característico e destaca a unidade semântica do conteúdo. Nesse caso, o silêncio - a autoexclusão política, o absenteísmo - se apresenta externamente como autoexclusão. No interior da comunidade judaica está em curso uma cisão e isso é sentido por Vigotski.

22 "Tentativas de pogroms" - com a brusca piora da situação econômica e os insucessos no front, teve início o boato de que foram exatamente os judeus que mais ganharam com a derrubada da monarquia. Assim, em abril de 1917, o comissário do Governo Provisório relatava de Odessa que os ânimos contra os judeus eram muito fortes e que "excessos poderiam ocorrer". Em Petrogrado e em outras cidades, começaram a surgir chamados que convocavam para os pogroms e também edições antissemitas periódicas. 60 povoados foram submetidos a pogroms: nas regiões de Kiev, de Podolsk e Volinsk. Por decisão de reuniões em vilas agrárias os judeus começaram a ser expulsos das aldeias. Houve explosão de antissemitismo no verão de 1917, tendo como pano de fundo o caos total e, às vezes, a total ingovernabilidade: a milícia novamente criada estava muito mal organizada, os órgãos da justiça não agiam e nas aldeias teve início a autojustiça.
}

tos, a especulação, o bolchevismo, a questão do poder, etc.), aqui, inevitavelmente, passam pelo prisma da tensa questão nacional.

Com esses três traços - o trabalho partidário intenso, o total declínio dos trabalhos comunitários em função da indiferença em relação a grandes questões judaicas e finalmente, o olhar preocupado para "os horizontes dos pogroms" - são, acredito, os momentos mais importantes na vida e nos ânimos dos judeus da província do território "demarcado".

Sei, sem dúvida, que o esclarecimento que essas linhas trazem contradiz o tipo comumente aceito de descrições provincianas. Pode ser que soe muito como uma nota pessimista. Mas, como diz o Talmude, não vemos as coisas como elas são, e sim como nos parecem. ${ }^{23}$

\section{Revista Novi Put', No 29, de 03 de setembro de 1917, colunas 31-32}

\section{Seção: Na província}

\section{Gomel}

\section{Conferência, s. $-d .^{24}$}

A conferência regional do partido socialdemocrata, ocorrida Moguiliov e que terminou há pouco, foi dedicada às questões da campanha eleitoral para a Assembleia Constituinte. É bem verdade que os preparativos para as eleições não tiveram início em todos os lugares, porém os socialdemocratas se anteciparam a todos os outros partidos com uma atividade enérgica.

A primeira questão resolvida foi sobre a lista de candidatos. Foi decidido caminhar separadamente, sem formar blocos com outros partidos socialistas, como aconteceu nas eleições municipais locais para as Dumas. É claro que as organizações partidárias socialdemocratas e a OGOJLPR - Bund caminharam juntas. A questão era apenas a distribuição de cadeiras entre socialdemocratas e OGOJLPR - Bund e dos candidatos da lista.

\footnotetext{
23 "Como diz o Talmude, não vemos as coisas como elas são, e sim como nos parecem" - aqui, Vigotski utiliza seu procedimento artístico muito comum de retorno ao tema e às palavras-chave dadas no início do artigo. Como já destacamos acima, na frase "palavras, palavras e palavras" também há uma menção indireta ao Talmude Babilônico (ver comentário 11). Vale notar que a fixação da "nota pessimista" e, paralelamente, a referência ao Talmude nos permitem concluir que Vigotski tenta ampliar o horizonte de sua opinião sobre os problemas concretos no contexto do destino histórico do povo judeu. E isso é uma escala histórico-cultural peculiar de análise dos problemas.

24 “Gomel. Conferência s.-d." - publicada na Revista semanal Novi Put' de 03 de setembro de 1917, na seção "Na Província", colunas 31-32. Assinada com o pseudônimo W. Como essa pequena nota é dedicada aos acontecimentos políticos em Gomel e foi publicada logo depois do artigo de L. S. Vigotski Notas da Província, existem fundamentos suficientes para supor que a autoria seja de Vigotski. No entanto, não conhecemos outros documentos assinados dessa forma por ele. Assim, pode-se supor que o pseudônimo "W" (duplo "V"), provavelmente, signifique que a nota teve dois autores, dois Vigodski: um deles, Lev Semionovitch, e o outro, o que é mais provável, seu pai, Semion Lvovitch que, naquele período, realizava um amplo trabalho social em Gomel (ver comentário 20). A coautoria com os demais parentes, como as irmãs Zinaida, Esther (Essia) e Klavdia e o primo David é menos provável.
} 
O primeiro lugar na lista foi ocupado pelo representante da OGOJLPR - Bund, doutor Lipets ${ }^{25}$ (Max); o segundo lugar pelo representante do Soviet local dos Deputados dos Operários e Soldados, ao praporschik ${ }^{26}$ Sevruk. ${ }^{27}$

O doutor Lipets era um velho militante da OGOJLPR - Bund, conhecido pelos moradores de Gomel em função do seu trabalho de alguns anos até a revolução atual; de acordo com os relatos, era um bom orador e, em geral, uma das forças de destaque do partido.

São curiosos alguns motivos apresentados na conferência e que levaram a deixar um representante da OGOJLPR - Bund a ocupar o primeiro lugar na lista.

Primeiramente, as organizações partidárias da OGO$J L P R$ - Bund, na região de Moguiliov, em geral, eram mais fortes e mais numerosas do que as organizações socialdemocratas; em segundo lugar, os representantes da OGOJLPR - Bund podem contar apenas com as regiões do antigo território demarcado para levarem seu representante à Assembleia Constituinte, pois, em todos os locais, eles irão juntamente com os socialdemocratas; $f$ nalmente, o antagonismo nacional nas localidades é tão forte que isso será não apenas uma clara manifestação e um chamado, mas também um fato repleto de significado no trabalho de educação política das massas.

Dessa forma, a posição da OGOJLPR - Bund definiu-se. "Sem fazer sombra à luta de classe com as tendências nacionais", etc.; menos clara é a posição que ocuparão os demais partidos judaicos e é totalmente misterioso o comportamento futuro de toda a enorme massa de judeus que permanecerá fora do partido.

A impressão geral é que por todo lado predomina a indecisão e que a questão da Assembleia Constituinte não será resolvida nas pequenas localidades, mas no centro. A massa sem partido está perdida e será que o Congresso previsto esclarecerá a ela a posição que ela própria assume.

\footnotetext{
25 "...doutor Lipets (Max)" - David Lipets, também conhecido como Max Goldfarb, David Petrovski, Camarada Bennet (nasceu em 1886; fuzilado pela Ordem de 10.09.1937 do Colegiado Militar do Tribunal Superior da URSS). Foi um homem que teve um destino incrível. Em 1902, ingressou na OGOJLPR -Bund. Durante a revolução de 1905, desenvolveu atividades junto aos trabalhadores de Dvinsk, Belostok e Gomel. Em 1907, participou do V Congresso do PSDTR como delegado da OGOJLPR - Bund. Paralelamente à atividade revolucionária, obteve o grau de Doutor em ciências econômicas na Universidade de Bruxelas (1910), tornou-se membro do Comitê Central da Federação socialista judaica da América e, posteriormente, redator do jornal judeu diário Forwards. No final de 1919, rompeu com a OGOJLPR -Bund e ingressou no PCR (b) e assumiu o sobrenome Petrovski; ocupou o cargo de chefe da Administração Central das Instituições de Ensino Superior do Exército Vermelho de trabalhadores e camponeses. Na primavera de 1924, foi enviado para trabalhar na Internacional Comunista. Aproximadamente durante três anos foi representante da executiva do Comintern nos EUA e na Grã-Bretanha, que funcionava clandestinamente, com o pseudônimo "Camarada Bennet"; tornou-se um dos dirigentes do movimento Comunista nos EUA. Nos anos de 1930, depois de trabalhar no Comintern, ocupou altos cargos no Comissariado do Povo para a Indústria Pesada e foi chefe da direção central das instituições de ensino.

${ }^{26}$ Praporschik refere-se a uma patente na hierarquia militar russa (N. da T.)

27 “...o praporschik Sevruk” - Polikarp Nikolaievitch Sevruk (não foi possível estabelecer as datas precisas de nascimento e morte), até 1916, foi ajudante de advogado do tribunal de justiça da região de Iekaterinburg do povoado de Verhrroturski. Em 1908, publicou a brochura A teoria de renda em Karl Marx: uma explicação popular. Em 06 de março de 1917, foi eleito o primeiro Sovie de Gomel e Sevruk foi seu presidente. Foi membro da ala moderada do PSDTR. Em 1917, passou para a posição a favor do enfrentamento revolucionário, que significava a união das ideias da revolução popular com o desejo de levar a guerra até a vitória final. Mais tarde, aderiu aos mencheviques e participou do congresso do partido menchevique em dezembro de 1917.
}

\section{Referências}

THE BIBLE. Books of the Holy Scriptures, Old and New Testament (canonical). Moscow: Rossiyskoe bibliograficheskoe obschestvo, 2012.

CHEKHOV, A. P. Words, words and words. In: . Polnoe sobranie sochineniy i pisem. Moscow: Nauka, 1975. v. 2, p. 113.

LEONTIEV, D. A.; SOBKIN, V. S. Psychology of art and psychological methodology in the early works of L. S. Vygotsky. In: Vestnik Moskovskogo universiteta. Moscow: Psychology, 1994. Series 14, 4, p. 35-44.

SOBKIN, V. S. Introductory article. L.S. Vygotsky: the outline of the socio-cultural context. In:_. Vygotsky L. S. Polnoe sobranie sochineniy. Moscow: Lev, 2015. v. 1, p. 10-75.

SOBKIN, V. S. On the study of the poetics of Vygotsky texts. In:_. [Nauchnoe tvorchestvo L.S. Vygotskogo $i$ sovremennaya psikhologiya]. Moscow: [s.n.], 1981. p. 143145.

SOBKIN, V. S. Comments on the theater reviews of Lev Vygotsky. [L. S. Vygotsky. Theatrical reviews]. Moscow: Institut Sotsiologii Obrazovaniya RAO, 2015.

SOBKIN, V. S. Comments on the unknown reportage of L. S. Vygotsky: impressions of the February Revolution. Voprosy psikhologii, Moscow, n. 5, p. 88-101, 2016.

SOBKIN, V. S.; KLIMOVA, T. A. Unknown Vygotsky: on the experience of translation from the Hebrew. Voprosy psikhologii, Moscow, n. 4, p. 1-20, 2016.

SOBKIN, V. S.; LEONTIEV, D. A. Psychology of art and psychological methodology in the early works of L. S. Vygotsky. In: Vestnik Moskovskogo universiteta. Moscow: Psychology, 1994. series 14, 4, p. 35-44.

SOBKIN, V. S.; MAZANOVA, V. S. Comments on theatrical reviews "Solovtsovskiy troupe tour" of L. S. Vygotsky. Dialog, Minsk, n. 9, p. 39-48, 2014a.

SOBKIN, V. S.; MAZANOVA, V. S. Comments on the «Theatrical Notes» of L. S. Vygotsky. Kul 'turno-istoricheskaya psikhologiya, Moscow, n. 3, p. 82-96, 2014 b.

SOBKIN, V. S.; MAZANOVA, V. S. What did Homel «Heather» of Lev Vygotsky say: the experience of reconstructing the sociocultural context. Voprosy psikhologii, Moscou, n. 6, p. 89$106,2014 \mathrm{c}$.

SOBKIN, V. S.; MAZANOVA, V. S. Previous comments on the theatrical review of L. S. Vygotsky. National'nyy psikhologicheskiy zhurnal, n. 1, p. 37-48, 2014d. Cross ${ }^{\text {Ref. }}$

SOBKIN, V. S.; MAZANOVA, V. S. Comments on «Theater and Revolution», the article by L. S. Vygotsky. Kulturnoistoricheskaya psikhologiya, n. 1, p. 91-113, 2015.

SOBKIN V. S., LYKOVA T. A., KOLOMIETS Y. O. Dynamics of drama students' personality features at theatre college. Procedia - Social and Behavioral Sciences, v. 233, p. 42-45, Oct. 2016. Cross ${ }^{\text {Ref. }}$

SOBKIN V. S. L. S. Vygotsky and the Theater. Journal of Russian \& East European Psychology, v. 53, n. 3, p. 1-92, Oct. 2016. Cross ${ }^{\text {Ref }}$

VYGODSKAYA, G. L.; LIFANOVA, T. M. Lev Vygotsky. $A$ life. Activities. Strokes to the portrait. Moscow: Smysl, 1996. 
VYGOTSKY, L. S. Thinking and speech. 5th ed. Moscow: Labirint, 1999.

VYGOTSKY, L. S. Psychology of Art. Moscow: Pedagogika, 1987.

ZINCHENKO, V. P. Mandelstam's sheperd's crook and Mamardashvili's smoking pipe: by the beginning of organic psychology. Moscow: Novaya Shkola, 1997.

Recebido em: 28 de novembro de 2017

Aceito em: 7 de dezembro de 2017 